\title{
Seismic interpretation and petrophysical analysis for hydrocarbon resource evaluation of 'Pennay' field, Niger Delta
}

\author{
Akindeji Opeyemi Fajana ${ }^{1} \cdot$ Michael Ayuk Ayuk ${ }^{2} \cdot$ Pius Adekunle Enikanselu $^{2}$ Ajibola Rasidat Oyebamiji ${ }^{3}$
}

Received: 17 May 2018 / Accepted: 2 November 2018 / Published online: 28 November 2018

(c) The Author(s) 2018

\begin{abstract}
Seismic interpretation and petrophysical assessment of borehole logs from seven wells were integrated with the aim of establishing the hydrocarbon reserves prior to field development which will involve huge monetary obligation. Four hydrocarbonbearing sands, namely Pennay 1, 2, 3 and 4 were delineated from borehole log data. Four horizons corresponding to near top of mapped hydrocarbon-bearing sands were used to produce time maps and then depth structural maps using checkshot data. Three major structure-building faults (F2, F3 and F5 which are normal, listric concave in nature) and two antithetic (F1 and F4) were identified. Structural closures identified as rollover anticlines and displayed on the time/depth structure maps suggest probable hydrocarbon accumulation at the upthrown side of the fault F4. Petrophysical analysis of the mapped reservoirs showed that the reservoirs are of good quality and are characterized with hydrocarbon saturation ranging from 56 to $72 \%$, volume of shale between 7 and $20 \%$ and porosity between 25 and $31 \%$. Pennay 2 and 3 have a better relative petrophysical ranking compared to other mapped reservoirs in the study area. Dissimilarity in the petrophysical parameters and the uncertainty in the reservoir properties of the four reservoirs were considered in calculating range of values of gross rock volume (GRV) and oil in place volume. This research study revealed that the discovered hydrocarbon reserve resource accumulations in the Pennay field for the four-mapped reservoir sand bodies have a total proven (1P) reserve resource estimate of 53.005MMBO at P90, 59.013MMBO at 2P/P50 and 65.898MMBO at 3P/P10. Reservoir C, the only interval with a gas cap, has a volume of 7737MMscf of free gas at 1P, 8893.2MMscf at 2P and 10185.2MMscf at 3P. These oil and gas volumetric values yield at $1 \mathrm{P} / \mathrm{P} 90$ total of $137.30 \mathrm{MMBOE}, 154.9 \mathrm{MMBOE}$ at $2 \mathrm{P}$ and $171.515 \mathrm{MMBOE}$ at $3 \mathrm{P}$. Reservoirs $\mathrm{B}$ and $\mathrm{D}$ have the highest recoverable oil at $1 \mathrm{P}, 2 \mathrm{P}$, and $3 \mathrm{P}$ values of 5.265MMBO and 10.70MMBO, 12.053MMBO and 5.783MMBO, 13.557MMBO and 6.244MMBO, respectively.
\end{abstract}

Keywords Seismic $\cdot$ Hydrocarbon $\cdot$ Porosity $\cdot$ Reserve $\cdot$ Volumetric $\cdot$ Productivity.

\section{Introduction}

Qualitative evaluation of hydrocarbon resources involves the integration of seismic and well data interpretations (Aizebeokhai and Olayinka 2011). P-wave seismic dataset, whether 2-D or 3-D, could be analyzed for mapping geological structures, understanding subsurface stratigraphy

Akindeji Opeyemi Fajana

akindeji.fajana@fuoye.edu.ng

1 Department of Geophysics, Federal University Oye-Ekiti, Oye Ekiti, Ekiti State, Nigeria

2 Department of Applied Geophysics, Federal University of Technology Akure, Akure, Ondo State, Nigeria

3 Department of Geology, Federal University Oye-Ekiti, Oye Ekiti, Ekiti State, Nigeria as well as delineating areal distribution of reservoir sands and their fluid. 3-D seismic datasets offer more advantages than 2-D because their dense grid of lines makes it possible to develop an accurate interpretation of structural and stratigraphic details (Saeland and Simpson 1982). Though 3-D surveys are relatively expensive, they are cost effective because they eliminate unnecessary development holes and increase recoverable hydrocarbon volumes through the discovery of isolated reservoir pools which otherwise might be missed (Sheriff and Geldart 1983). Niger Delta area is one of the most productive basins in Africa typified by six depobelts (OPEC 2017). This hydrocarbon-rich basin is ranked eighth amid the world's hydrocarbon provinces with further auspicious reserves not yet discovered as search for petroleum proceeds into the deeper offshore. The Niger Delta hydrocarbon province has some verified recoverable 
reserves of around 37,452 million barrels (mmbbl) of oil (OPEC 2017) and 5.1 trillion cubic metres of gas resources (BP 2014). Current massive oil discoveries in the deep-water zones of the Delta suggest that the province will continue to be a focus of exploration activities (Corredor et al. 2005). It has, therefore, become necessary to apply exploration and production technologies to harness these hydrocarbon resources. The 'Pennay' field is around the boundary between Coastal and Central Swamps, and has not been fully explored and exploited to its potential (Billoti and Shaw 2005). Although, seven exploratory wells have been drilled (Fig. 1) to extract useful information about the field, there still exists some level of uncertainty regarding the reservoir structure and internal anisotropy, fluid properties and hydrocarbon volume. Qualitative evaluation of hydrocarbon resources involves the integration of seismic and well data interpretations. Conventional interpretation of seismic data includes horizon and fault picking on reflection seismic sections. A seismic interpreter integrates geology, geophysics, and engineering, and equally makes simplifying assumptions to get an interpretation job done. Nevertheless, properties of hydrocarbon-bearing reservoirs such as porosity, fluid saturation and net to gross are derived from petrophysical interpretation of well log data. Integrating log-derived reservoir properties with seismic data and structural interpretation enable an interpretation team to quantify subsurface hydrocarbon accumulations, generate prospects and leads, classify petroleum resources, determine probability of success, rank resources, plan future wells, reduce exploration and drilling risks, and also increase success rate for drillable prospects (Adeoye and Enikanselu 2009). This study aims to improve the understanding of the subsurface geology of the field with distinct attention in estimating the possible oil and gas initially in place considering range of reservoir properties and structural uncertainty. This was accomplished by integrating and interpreting the 3D seismic data to define the reservoir geometry, evaluating the petrophysical parameters of the reservoirs and determining the lateral extent of the hydrocarbon-bearing zone using the delineated fluid contacts; this helped to estimate the gross rock volume (GRV) and hydrocarbon volume. Onayemi and Oladele (2014) have shown that when 3D seismic data are integrated with well $\log$ data, it provides a powerful tool to determine the structural frame work and estimation of reserves of a field
Fig. 1 Base map of the study area

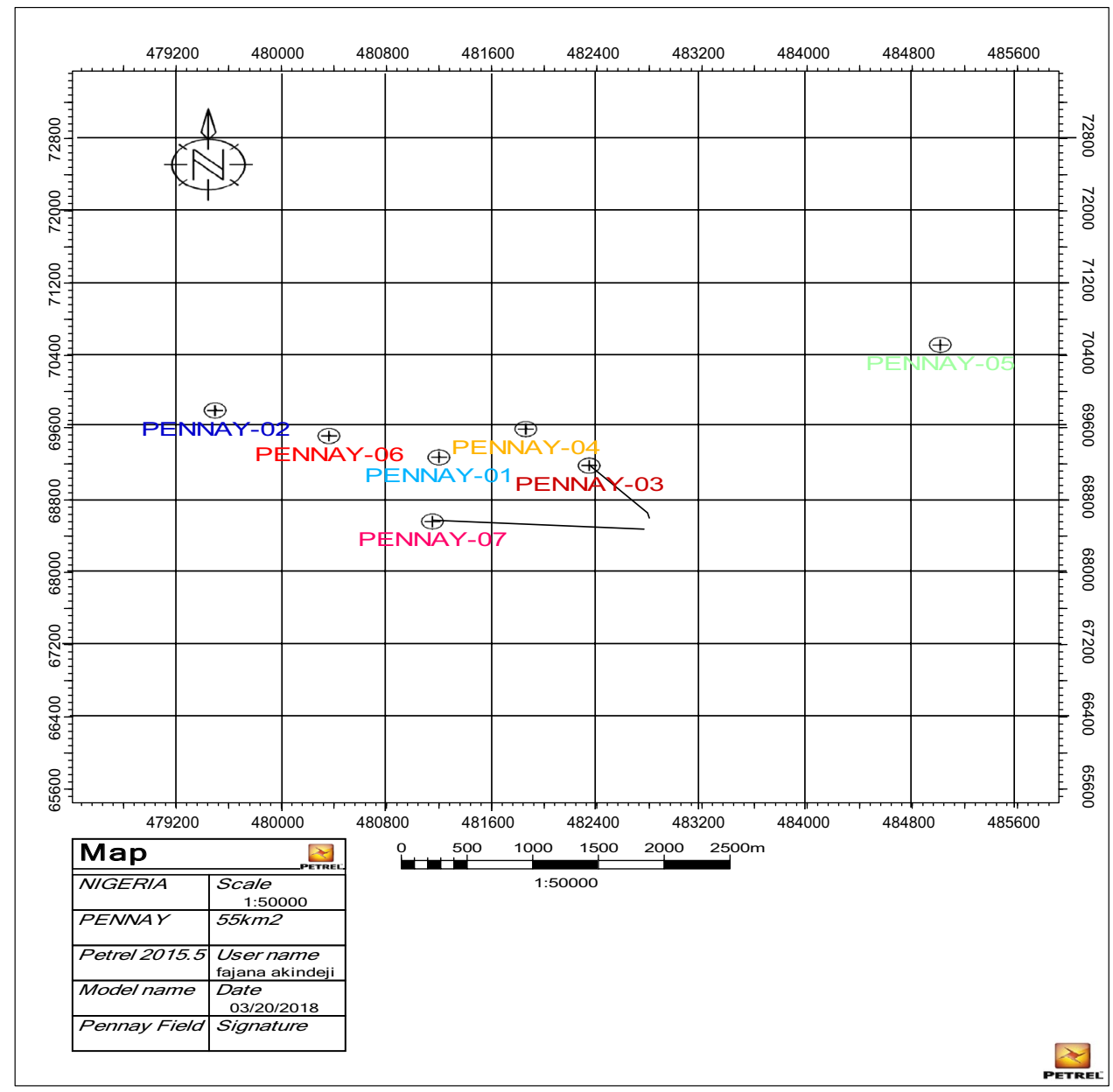


(Futalan et al. 2012; Oyedele et al. 2013; Ihianle et al. 2013; Amigun et al. 2014; Onayemi and Oladele 2014). Consequently, this study comprises imaging the subsurface structures, determination of reservoir properties and estimation of volumes for hydrocarbons within reservoirs of the Pennay field using integrated approach of petrophysical, seismic and volumetric methods.

\section{Geological framework}

The study area is located in the Gulf of Guinea on the west coast of Central Africa (Fig. 2) and outspreads all over the Niger Delta area (Stacher 1994). During the Tertiary, the Niger Delta built out into the Atlantic Ocean at the mouth of the Niger Benue river system, an area of catchment that covers more than a million square kilometres of mainly savannah-covered plains. The delta with the sub-aerial portion covers about 75,000 $\mathrm{km}^{2}$ and covers more than $300 \mathrm{~km}$ from climax to mouth. The tertiary sequence of Niger Delta is subdivided into three broad stratigraphic units (Fig. 3): Akata, Agbada and Benin Formations in ascending order of sedimentation. Akata Formation (Marine Shale) is a fully marine deposit, characterized by uniform shale development with lenses of siltstone and sandstone. It is generally overpressured (i.e., under-compacted). The boundaries between each formation are not always sharp, but gradual transition is common. This formation is believed to have been deposited in front of the advancing delta and has a maximum thickness of over $6100 \mathrm{~m}$ in the central part of the delta. Akata shale is thermally matured and is considered to be the main source rock where hydrocarbons are generated. Agbada Formation (Paralic clastics) overlies the Akata Formation and underlies the Benin Formation. Agbada Formation is a paralic sequence consisting of alternation of sands (sandstones) and shale which are the result of differential subsidence, variation in sediment supply and shift of the delta depositional axes which result in local transgression and regression. Considerable problems arise with the definition of the top and base of the Agbada Formation. The top is usually defined by local geologist as the base of fresh-water invasion, whereas the base is often placed at the onset of hard over-pressures during drilling. This sequence is connected with sedimentary growth faulting (Fig. 4) and contains the bulk of the hydrocarbon reservoirs. The Agbada Formation is divided into four members namely:

1. D-1: This is predominantly regressive, marine sand and shale that contains minor oil and gas reservoirs.

2. Qua-Iboe: It consists of thick piles of shale with thin intercalated sands that are possible oil and gas reservoirs in some places.

3. Rubble beds: It lies directly below the Qua-Iboe as truncated beds.

4. Biafra member: It is predominantly sands and shale, and it consists of the principal oil and gas reservoir. It is divided into upper, middle and lower.

Benin Formation (continental sands) occurs in the whole Niger Delta from Benin-Onitsha in the North and
Fig. 2 Niger Delta concession map showing study area. Modified from Doust and Omatsola (1990) and Stacher (1994)

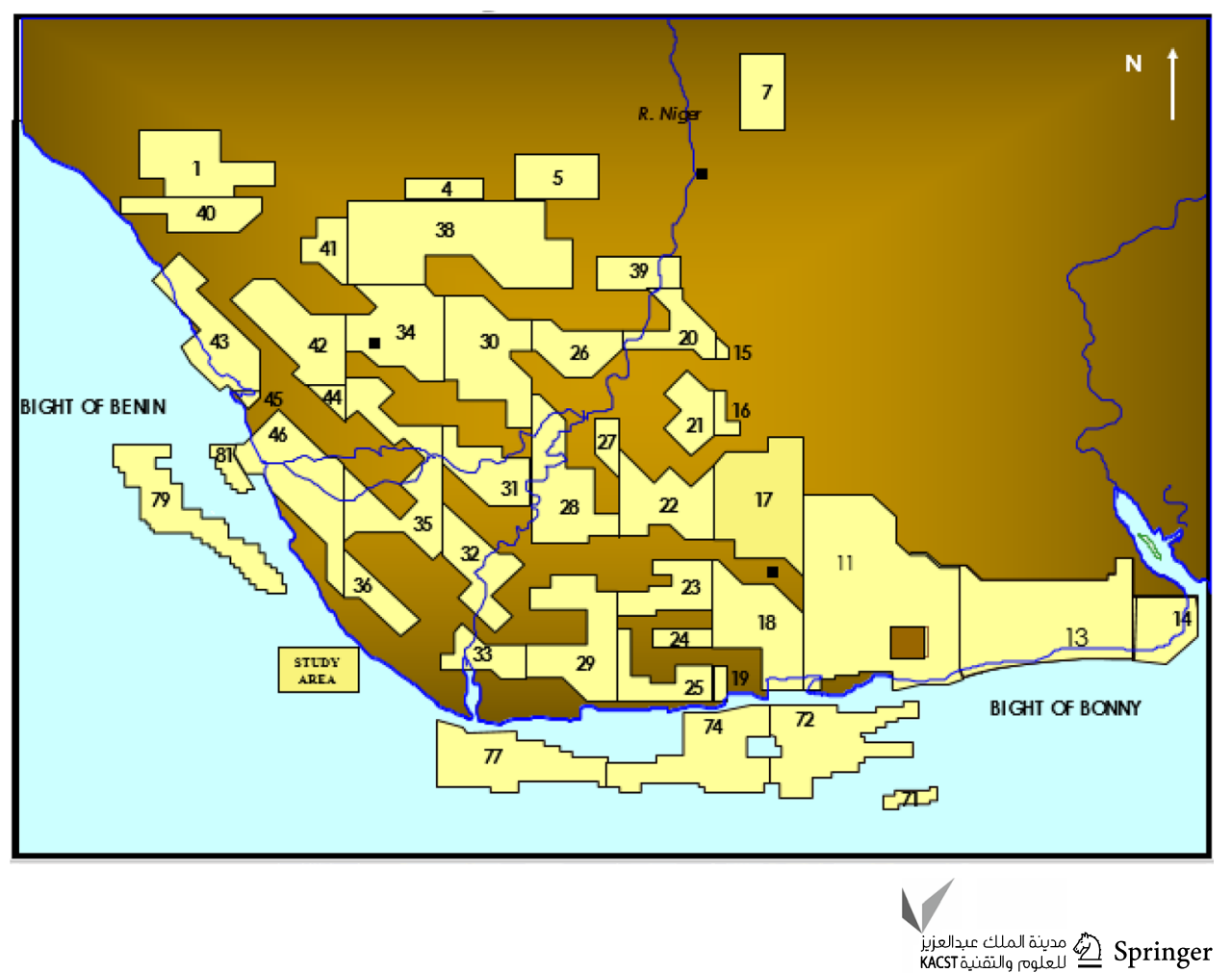


Fig. 3 Stratigraphic column showing the three formations of the Niger Delta. Shannon and Naylor (1989) and Doust and Omatsola (1990)
SOUTHWEST

NORTHEAST

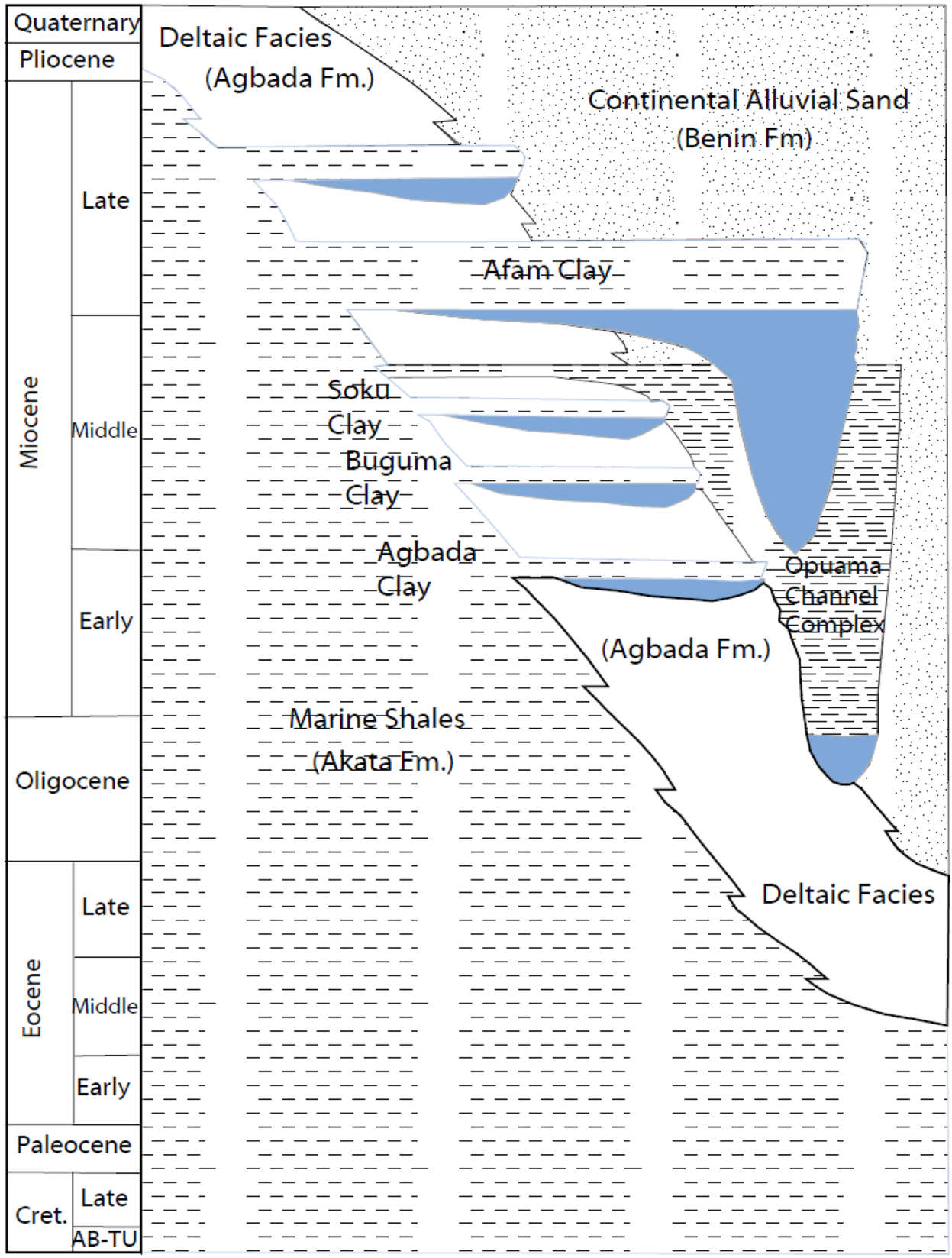

Extent of erosional truncation extends beyond the present coastline. This is composed of entirely non-marine sand and it is the shallowest part of the sequence. It has massive continental (fluvative) grave, which consists of shale and sand with thickness up to $200 \mathrm{~km}$. It was deposited in alluvial or upper coastal plain environments following a southward shift of deltaic deposition into a new depobelts. This is a terrestrial sequence. It is the uppermost and shallowest stratigraphic unit in the Niger Delta. It consists of poorly sorted, medium to fine grained, fresh water-bearing sands and conglomerates, with a few shale intercalations which become more abundant towards the base. The thickness of this formation is about $2100 \mathrm{~m}$, and it traps non-commercial quantities of hydrocarbon and has sand percentage of over $80 \%$. Corredor et al. (2005). The age of this formation is Oligocene (Short and Stauble 1967). The 'Pennay' field is situated offshore, southwestern Niger Delta and is complexly faulted within the basin. The topmost Benin sands, middle parallic Agbada Formation, and the marine shales of Akata Formation are well represented in the field. The field is characterized by only normal faults, 
Fig. 4 Principal Types of oilfield structures in the Niger Delta with schematic indications of common trapping configurations (after Tuttle et al. 1999)

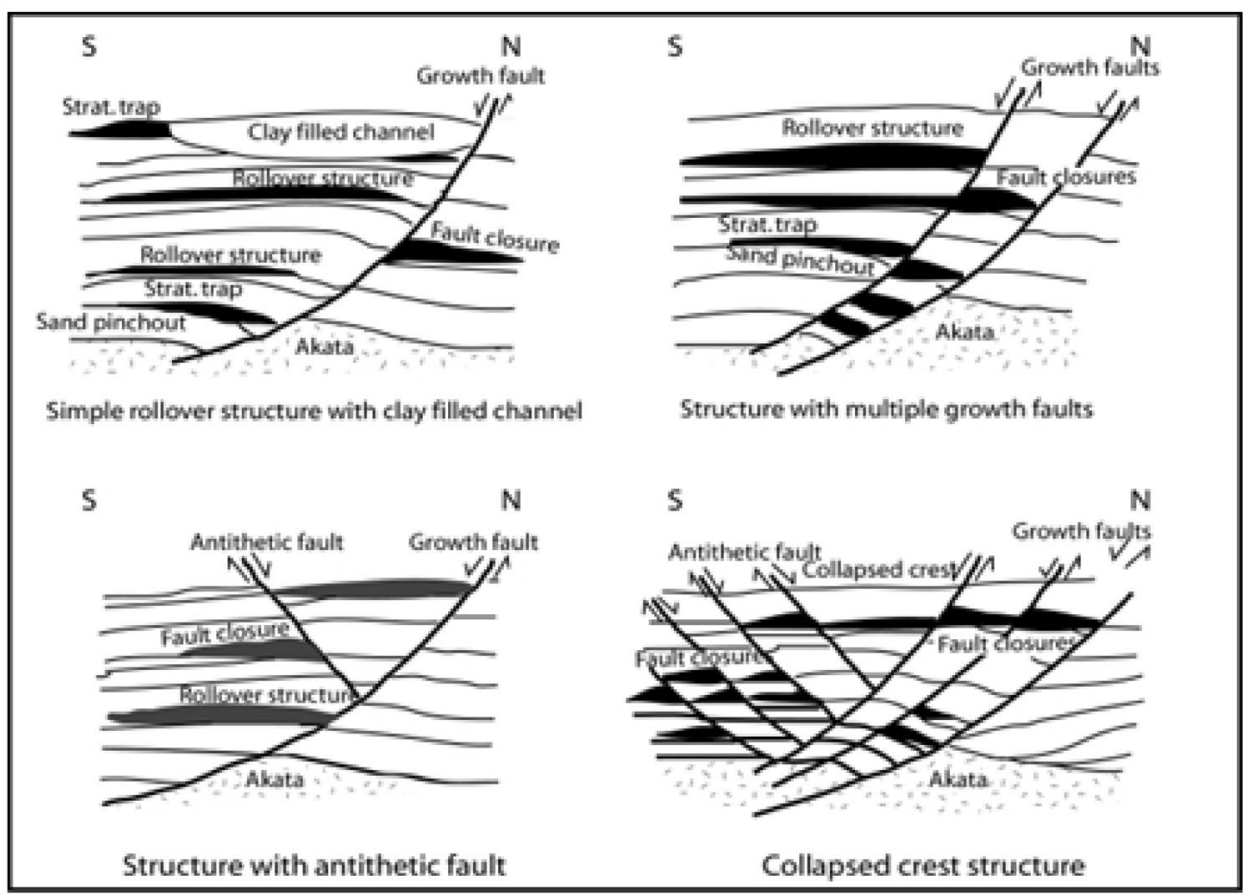

which indicate an extensional deformational phase during subsidence and uplift associated with instability of the overpressured shale in the Late Cretaceous.

\section{Datasets and methodology}

The datasets available for this study (Table 1) include a base map, 3-D seismic volume, suites of borehole $\log \mathrm{s}$ for seven wells (Figs. 5, 6) and checkshot data. The 3D seismic data volume is a post-stack, zero-phase, migrated, 58 -folds, with dominant bandwidth of $65 \mathrm{~Hz}$. It consists of 401 inlines and 201 crosslines. Lithologies in the field were identified via gamma ray log and this was possible by establishing shale baseline of 70API within gamma ray $\log$. The negative deviation from the shale baseline indicates that the lithology is sand and positive deviation to the right indicates that the lithology is shale. Hydrocarbon-bearing reservoirs in the seven wells were identified using area that has high resistivity values and low gamma ray which are an indication of hydrocarbon and sand unit, respectively; these areas were delineated and mapped as reservoirs. The 3D seismic data volume was used for fault interpretation and was quality checked using the 3D window. Identified faults were assigned names, colour coded (Fig. 7). Four key seismic horizons were tied to the seismic section with the well tops which were defined from the gamma ray log. The resistivity logs were used to determine potential hydrocarbon-bearing zones. Qualities such as continuity, event strength, amplitude and coherency were
Table 1 Data available for interpretation

\begin{tabular}{llllllll}
\hline Data & Pennay 1 & Pennay 2 & Pennay 3 & Pennay 4 & Pennay 5 & Pennay 6 & Pennay 7 \\
\hline Well headers & $\bullet$ & $\bullet$ & $\bullet$ & $\bullet$ & $\bullet$ & $\bullet$ & $\bullet$ \\
Deviation surveys & & & & & & & $\bullet$ \\
Gamma ray log & $\bullet$ & $\bullet$ & $\bullet$ & $\bullet$ & $\bullet$ & $\bullet$ & $\bullet$ \\
Density $\log$ & $\bullet$ & $\bullet$ & $\bullet$ & $\bullet$ & $\bullet$ & $\bullet$ & $\bullet$ \\
Sonic log & $\bullet$ & $\bullet$ & $\bullet$ & $\bullet$ & $\bullet$ & $\bullet$ & $\bullet$ \\
Resistivity log & $\bullet$ & $\bullet$ & $\bullet$ & $\bullet$ & $\bullet$ & $\bullet$ & $\bullet$ \\
Neutron log & $\bullet$ & $\bullet$ & $\bullet$ & $\bullet$ & $\bullet$ & $\bullet$ & $\bullet$ \\
Spontaneous potential log & $\bullet$ & $\bullet$ & $\bullet$ & $\bullet$ & $\bullet$ & $\bullet$ & $\bullet$ \\
Checkshot & & & $\bullet$ & $\bullet$ & $\bullet$ & \\
3D Seismic volume & & & & & &
\end{tabular}




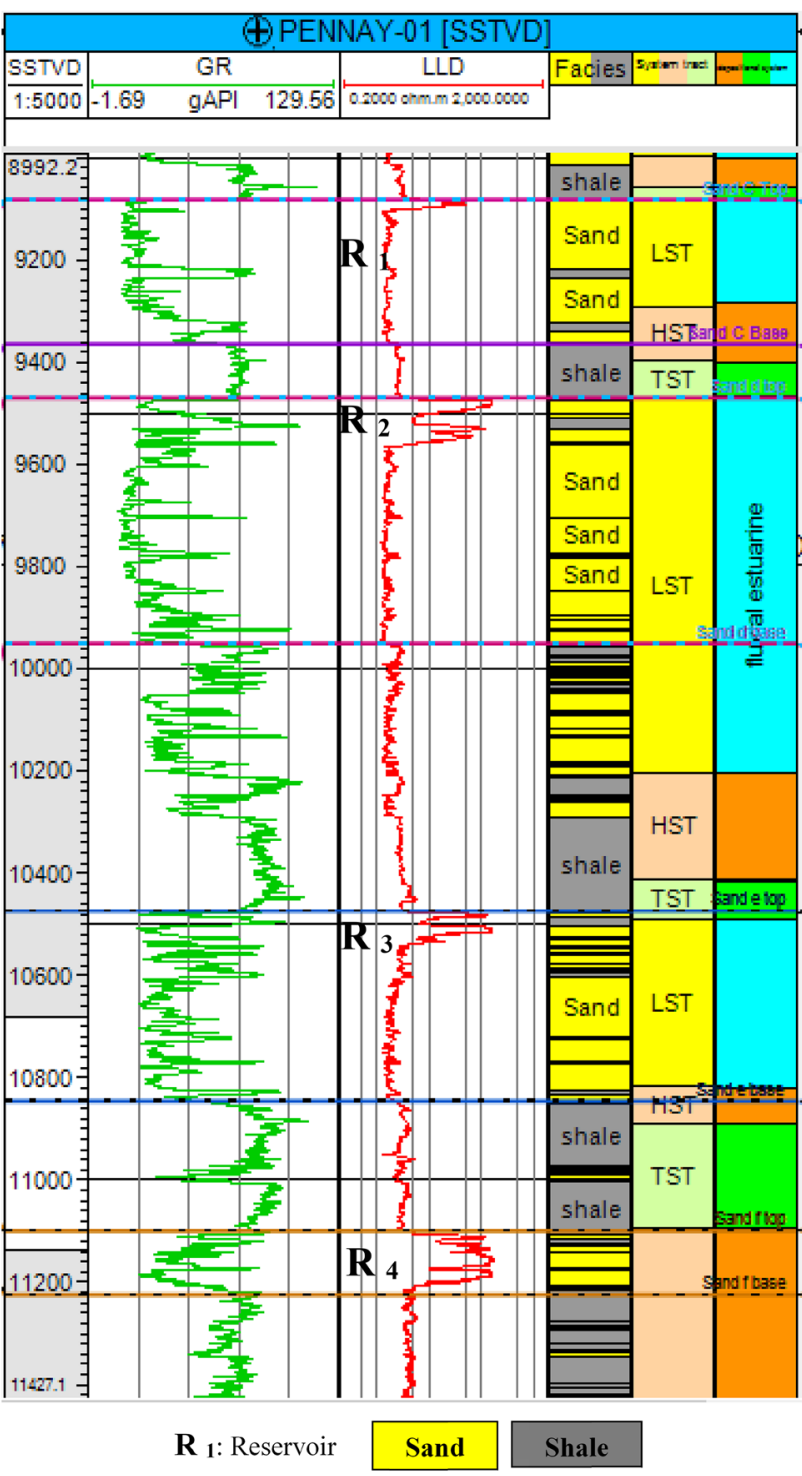

Fig. 5 Composite well logs and lithologic interpretation of well 1

used as guides in mapping the continuity of the horizons. These analyses precede the interpretation of the seismic horizons. Five faults were map all through the field and it was found out that the major faults are growth fault.

\section{Qualitative interpretation}

This involves the use of the suite of logs, such as resistivity (ILD), gamma ray, neutron and density logs to identify lithology within the five wells, and the following generalized formula were used to estimate the petrophysical parameters such as water saturation, hydrocarbon saturation, porosity and permeability.

\section{True formation resistivity $\left(R_{\mathrm{t}}\right)$}

This is the true resistivity of a formation. It is measured by a deep reading resistivity log such as deep induction log (ILD) or deep laterolog (LLD). The ILD log signature across each reservoir formation in each well is examined and sampled to obtain its average value in each of the hydrocarbon reservoir. This gives the true resistivity $R_{\mathrm{t}}$ of each reservoir.

\section{Gamma ray index $\left(I_{G R}\right)$}

Determining the gamma ray index $\left(I_{\mathrm{GR}}\right)$ is the first step needed to evaluate the volume of shale $V_{\mathrm{sh}}$ in porous reservoirs. They are applied in the analysis of shaly sands. The $I_{\mathrm{GR}}$ is given by

$I_{\mathrm{GR}}=\frac{\mathrm{GR} \log -\mathrm{GRmin}}{\mathrm{GRmax}-\mathrm{GRmin}}$,

where $\mathrm{I}_{\mathrm{GR}}$ : gamma ray index, $\mathrm{GR}_{\mathrm{log}}$ : gamma ray reading of formation, $\mathrm{GR}_{\min }$ : minimum gamma ray response in a clean sand or carbonate zone, $\mathrm{GR}_{\max }$ : maximum gamma ray response in a shaly formation, and $\mathrm{GR}_{\text {log }}, \mathrm{GR}_{\min }$ and $\mathrm{GR}_{\max }$ are measured in American Petroleum Institute (API) units.

\section{Quantitative interpretation}

This involves the estimation of petrophysical parameters such as porosity, water saturation, hydrocarbon saturation, permeability, movable hydrocarbon index, bulk volume water, and residual oil saturation. Cross-plots of the estimated parameters were generated.

\section{Volume of shale $\left(V_{s h}\right)$}

The volume of shale $V_{\mathrm{sh}}$ was mathematically obtained from the following relationships (Eq. 3) using the $\mathrm{I}_{\mathrm{GR}}$ using Microsoft excel package.

1. Dresser Atlas (1979) formulae:

$V_{\mathrm{sh}}=0.33\left[2^{\left(2 \times I_{\text {GR }}\right)}-1.0\right] \quad$ (For older and consolidated rocks),

$V_{\mathrm{sh}}=0.083\left[2^{\left(3.7 \times I_{\mathrm{GR}}\right)}-1.0\right] \quad$ (Tertiary and unconsolidated rocks).

\section{Linear relationship: $V_{\mathrm{sh}}=I_{\mathrm{GR}}$,}

$V_{\mathrm{sh}}=1.7\left[3.38-\left(I_{\mathrm{GR}}+0.7\right)^{2}\right]^{1 / 2}$.

3. Steiber (1984) relationship:

$V_{\mathrm{sh}}=\frac{\left(0.5 \times I_{\mathrm{GR}}\right)}{\left(1.5-I_{\mathrm{GR}}\right)}$.

4. Bateman (1977) formulae: 


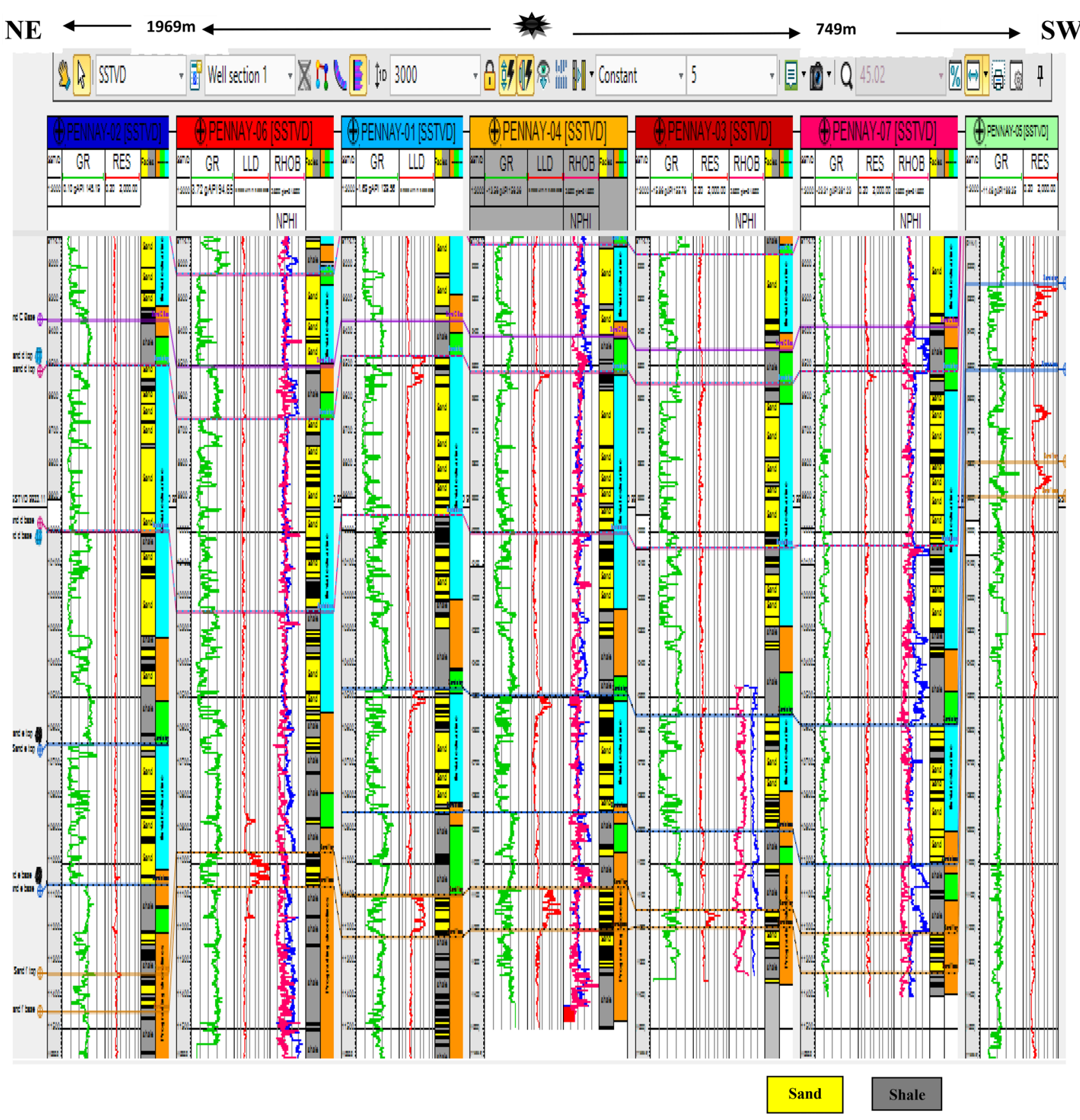

Fig. 6 Lithostratigraphic correlation section across the reservoirs

$V_{\mathrm{sh}}=I_{\mathrm{GR}}{ }^{\left(I_{\mathrm{GR}}+\text { GR factor }\right)}$.

\section{Porosity $(\varnothing)$}

Based on the available data, density-derived porosity $\emptyset_{\mathrm{DEN}}$ was computed and corrected for shale effect using the Dresser Atlas, (1979) equation. The density-derived porosity $\emptyset_{\mathrm{DEN}}$ is given by
$\varnothing_{\mathrm{DEN}}=\left(\frac{\rho \mathrm{ma}-\rho \mathrm{b}}{\rho \mathrm{ma}-\rho \mathrm{f}}\right)$.

The corrected density porosity, after Dresser Atlas, (1979) is given by

$\varnothing=\left(\frac{\rho m a-\rho b}{\rho m a-\rho f}\right)-V_{\text {sh }}\left(\frac{\rho m a-\rho s h}{\rho m a-\rho f}\right)$, 


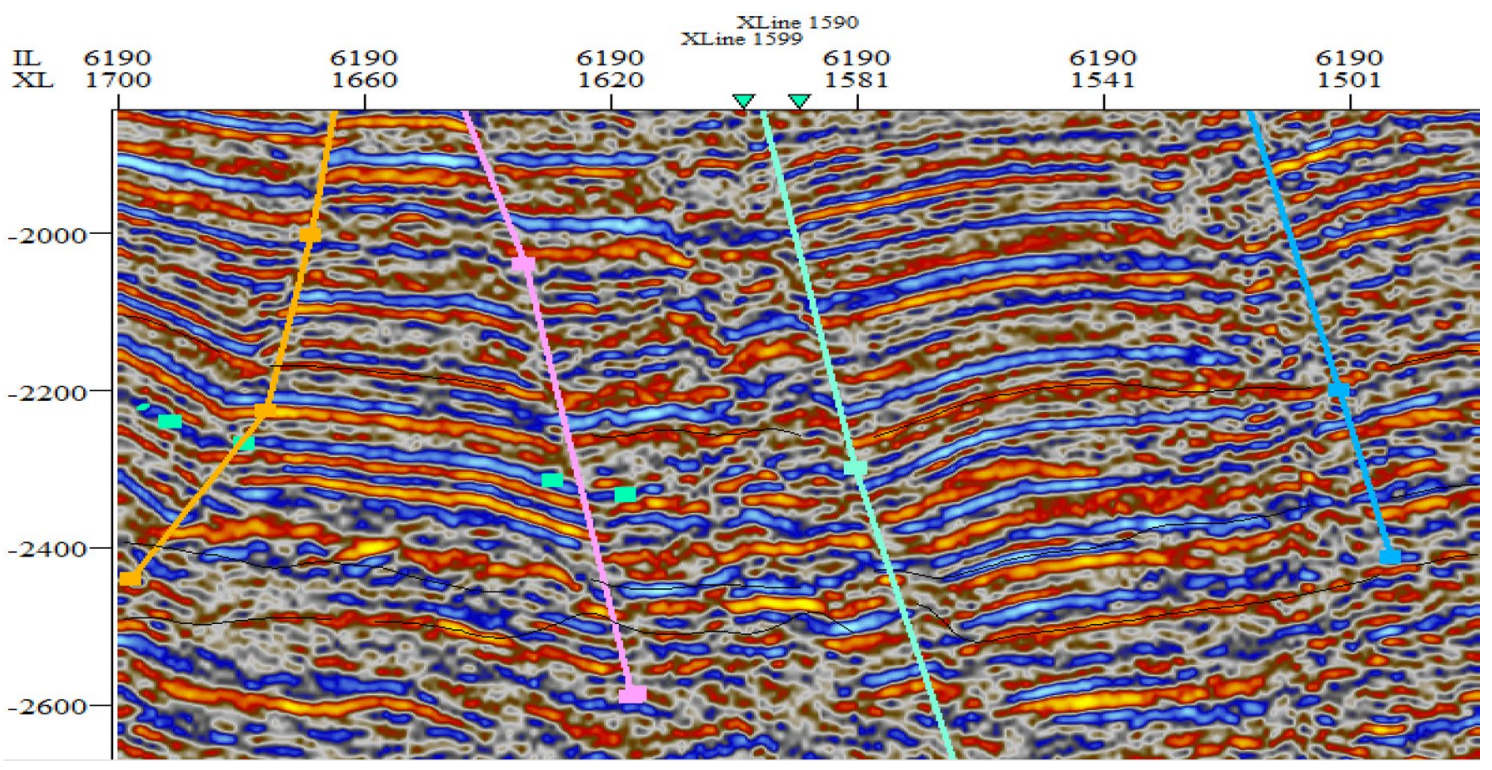

Fig. 7 Typical interpreted seismic section (Inline 6190)

where

$\mathrm{V}_{\mathrm{sh}} \quad$ Volume of shale

$\emptyset_{\text {DEN }}$ Density-derived porosity

$\varnothing \quad$ Corrected density porosity for shale effect

$\ell_{\text {ma }}$ Matrix density of formation. This is given as $2.68 \mathrm{~g} /$ cc in the log header.

$\ell_{\mathrm{b}} \quad$ Bulk density of formation. It is obtained as the log response in each reservoir.

$\ell_{\mathrm{f}} \quad$ Fluid density. This is given as $1.0 \mathrm{~g} / \mathrm{cc}$ in the $\log$ header.

$\ell_{\text {sh }} \quad$ Bulk density of adjacent shale. This is the density log response in the adjacent shale zone to each reservoir formation.

\section{Criteria of the $ø$ grades}

$$
\begin{aligned}
& \emptyset<5 \% \text { : negligible. } \\
& 5 \%<\emptyset<10 \% \text { : poor. } \\
& 10 \%<\varnothing<15 \% \text { : fair. } \\
& 15 \%<\varnothing<25 \% \text { : good. } \\
& \emptyset>25 \% \text { : Excellent. }
\end{aligned}
$$

\section{Formation factor $(F)$ estimation}

This fundamentally expresses the ratio of the resistivity of a formation to the resistivity of the water with which it is saturated. In borehole geophysics, the formation factor F is given by

$$
F=\frac{a}{m}
$$

where

$$
\begin{array}{ll}
\text { a } & \text { Tortuosity factor } \\
\mathrm{m} & \text { Cementation factor } \\
\varnothing & \text { Porosity }
\end{array}
$$

where $a=1$ and $m=1.8$.

\section{Water saturation estimation $\left(S_{w}\right)$}

The water saturation in each of the reservoir formation was computed using the Archie (1942) formula. It is given by the following equation:

$S_{\mathrm{w}}=\left(F \times \frac{R_{\mathrm{w}}}{R_{\mathrm{t}}}\right)^{1 / n}$,

where

F Formation factor

$\mathrm{R}_{\mathrm{w}}$ Formation water resistivity at formation temperature

$\mathrm{R}_{\mathrm{t}} \quad$ True formation resistivity

$\mathrm{n}$ Saturation exponent. This was given as 2.0. This was obtained from the log header.

\section{Hydrocarbon saturation $\left(S_{h}\right)$}

The hydrocarbon saturation was computed using Eq. 3.11. $\mathrm{S}_{\mathrm{h}}$ is given by

$S_{\mathrm{h}}=1-S_{\mathrm{W}}$. 
Irreducible water saturation $\left(S_{\text {wirr }}\right):_{n}$

Water saturation at irreducible water $S_{\text {wirr }}$ was given by

$S_{\text {wirr }}=\sqrt{\frac{F}{2000}}$.

\section{Absolute permeability $(K)$}

Absolute permeability is the ability of a rock to transmit a single fluid when it is $100 \%$ saturated with that fluid. It is measured in millidarcy (md).

The absolute permeability $K$ is given by

$K^{1 / 2}=\frac{100 \times \emptyset^{2.25}}{S_{\mathrm{w} \text { irr }}}$.

This is called the Timur (1968) relationship.

$K^{1 / 2}=\frac{250 \times \emptyset^{3}}{S_{\mathrm{w} \mathrm{irr}}}$.

This is the Tixier (1956) relationship. This is applied in this study to compute the permeability for each reservoir rock.

$\varnothing$ is the porosity. $S_{\text {wirr }}$ is the irreducible water saturation.

\section{Relative permeability $\left(K_{\mathrm{r}}\right)$}

The relative permeability $K_{\mathrm{r}}$ is the ratio between effective permeability of fluid at partial saturation, and the permeability at $100 \%$ saturation (absolute permeability). It follows that when the relative permeability of a formation water is zero, then the formation will produce water-free hydrocarbons (i.e, when $K_{\mathrm{rw}}=0$ then $K_{\mathrm{ro}}=100 \%$ ). With increasing relative permeability to water $K_{\mathrm{rw}}$, the formation will produce increasing amounts of water relative to hydrocarbons (Asquith 2004).

The relative permeability to water $K_{\mathrm{rw}}$ is given by

$K_{\mathrm{rw}}=\left[\frac{\left(S_{\mathrm{w}-S_{\mathrm{wirr}}}\right)}{\left(1-S_{\mathrm{w} \mathrm{irr}}\right)}\right]^{3}$.

The relative permeability to oil $K_{\mathrm{ro}}$ is given by

$K_{\mathrm{ro}}=\left[\frac{S_{\mathrm{h}}}{\left(1-S_{\mathrm{w} \text { irr }}\right)}\right]^{2.1}$.

\section{Effective permeability $\left(K_{\mathrm{w}}\right.$ and $\left.K_{\mathrm{o}}\right)$}

Effective permeability describes a situation where there are two fluids in a rock. The ability of the rock to transmit one of the fluids in the presence of the other, when the two fluids are immiscible is a function of the effective permeability of the rock.

The effective permeability to water $K_{\mathrm{w}}$ is given by

$K_{\mathrm{w}}=K_{\mathrm{rw}} \times K$.

The effective permeability to oil $K_{\mathrm{o}}$ is given thus as

$K_{\mathrm{o}}=K_{\text {ro }} \times K$.

\section{Hydrocarbon pore volume ( $\mathrm{Hcpv})$}

This is the fraction or the percentage of bulk reservoir volume that is occupied by hydrocarbon. It is given by

$\mathrm{Hcpv}=\emptyset \times\left(1-S_{\mathrm{W}}\right)=\emptyset \times S_{\mathrm{h}}$,

where

$\varnothing \quad$ is the porosity

$\mathrm{S}_{\mathrm{w}} \quad$ Water saturation

$\mathrm{S}_{\mathrm{h}}$ Hydrocarbon saturation.

Also in this study, volumetric estimation of hydrocarbon was carried out with varying degrees of uncertainty using a deterministic approach. The original oil in place (OOIP) was estimated using the gross rock volume (GRV) as well as net to gross (NTG), porosity $(\varnothing)$ and water saturation $\left(\mathrm{S}_{\mathrm{w}}\right)$ data deduced from the formation evaluation results. The OOIP in Acre-ft was converted to million barrels (MMB) using the formulae stated below:

$\mathrm{OOIP}=\left[\mathrm{GRV} \times \mathrm{NTG} \times \emptyset \times\left(1-S_{\mathrm{W}}\right) \times 7758.38\right] \div 10^{6}$,

Stock Tank Oil Initially In Place $($ STOIIP $)=$ OOIP $\div B \mathrm{o}_{i}$,

$\mathrm{GIIP}=\mathrm{GRV} \times \mathrm{NTG} \times \emptyset \times\left(1-S_{\mathrm{W}}\right) \times 0.04356$,

Stock Tank Gas Initially In Place $($ STGIIP $)=$ GIIP $\div B g_{i}$,

Estimated Ultimate Recovery $=\mathrm{STOIIP} \div \mathrm{RF}$, where

7758/10 $0^{6}$ Conversion factor: million barrels per Acre- $\mathrm{ft}$

0.04356 Conversion factor: million standard cubic feet per Acre-ft

GRV Gross rock volume in acre-ft

NTG Net to gross

$\varnothing \quad$ Porosity

$\mathrm{S}_{\mathrm{w}} \quad$ Water saturation

OOIP Original oil in place

GIIP Gas initially in place

STOIIP Stock tank oil initially in place 
STGIIP Stock tank gas initially in place

$\mathrm{Bo}_{\mathrm{i}} \quad$ Formation volume factor for oil

$\mathrm{Bg}_{\mathrm{i}} \quad$ Formation volume factor for gas

RF Recovery factor

\section{Results and discussion}

\section{Seismic structural analysis}

Structural interpretation was performed to identify and assign faults found in the 3-D seismic volume. Time and depth structure maps in combination with well logs were used to produce for four horizons, namely $\mathrm{H} 1-\mathrm{H} 4$. Three major growth faults (F2, F3 and F5 which are normal, listric concave in nature) and two antithetic (F1 and F4) were identified. Structural closures identified as rollover anticlines and displayed on the time/depth structure maps suggest probable hydrocarbon accumulation at the upthrown side of the fault F4. Structural time maps where values are in two-way seismic travel time were generated for the mapped horizons using fault polygons, boundary polygons and the interpreted horizon. Structural depth maps were also generated and they show the true position of structures and mapped faults within the study area as shown in Fig. 8a-d.

The depth structural map of sand A is shown in Fig. 8a; the contour lines vary from -2260 to $-2380 \mathrm{~m}$. The lowest point on this map is at the north-western part with depth values from -2200 to $-2260 \mathrm{~m}$. On this map, there are five faults; the two main faults (F3 and F5) are responsible for the hydrocarbon accumulation. The crest of the structure is structurally high; hence it suggests hydrocarbon prospect. It can be observed that the existing wells are situated close to and on the flank of the mapped structural high. The depth structural map of sand B is shown in Fig. 8b; the contour lines vary from -2450 to $-2900 \mathrm{~m}$. The lowest point on this map is at southwestern part with depth values of -2375 to $-2450 \mathrm{~m}$. There are five faults on the map; the major faults (F3 and F5) are responsible for the hydrocarbon accumulation. The crest of the structure is structurally high; hence it is a hydrocarbon prospect. It can be observed that the existing wells are situated close to and on the flank of the mapped structural high. This also confirms the validity of the existing interpretation. The depth structural map of sand $\mathrm{C}$ is shown in Fig. 8c; the contour lines vary from -2450 to $-2900 \mathrm{~m}$. The lowest point on this map is at the southwestern part with depth values from -2375 to $-2900 \mathrm{~m}$. One major fault was mapped which is the main fault that is responsible for the hydrocarbon accumulation. The crest of the structure is structurally high; hence it is a region of interest for hydrocarbon exploration. It can be observed that the existing wells are situated close to and on the flank of the mapped structural high.
The depth structural map of sand D is shown in Fig. 8d; the contour lines vary from -3000 to $-3500 \mathrm{~m}$. The lowest point on this map is at the southwestern part with depth values from -3000 to $-3125 \mathrm{~m}$. On this map, one major fault was mapped which is the main fault that is likely responsible for the hydrocarbon accumulation. The crest of the structure is structurally high; hence it is a hydrocarbon prospect. It can be observed that the existing wells are situated close to and on the flank of the mapped structural high. This also confirms the validity of the existing interpretation.

\section{Results of petrophysical evaluation}

The petrophysical evaluation of the reservoir units forms a qualitative approach of interpreting the well logs. All computations were done using relevant equations and typical results obtained are presented in Tables 2, 3 and 4. Reservoir A is located within a depth range of $2294-2440 \mathrm{~m}$ and extends across all the wells. It has an average porosity of $28 \%$, hydrocarbon saturation of $60 \%$, permeability of $721 \mathrm{md}$, volume of shale of $12 \%$, net to gross sand ratio of 0.99 and water saturation of $39.7 \%$. The reservoir has an average porosity of $28 \%$, which is a good and significant characteristic of prolific reservoir according to criteria of the porosity $(\phi)$ grades by Bateman and Konen 1977. The reservoir in sand B was penetrated at depths 2459-2563 m for Pennay 1, 2458-2727 m for Pennay 2, 2477-2691 m for Pennay 3, 2478-2684 for Pennay 4 and 2456-2747 $\mathrm{m}$ for Pennay 5. Gross reservoir thickness is $108 \mathrm{~m}, 269 \mathrm{~m}, 28 \mathrm{~m}, 372 \mathrm{~m}, 133 \mathrm{~m}$ and $110 \mathrm{~m}$ in Pennay $1-5$, respectively. It was characterized by gross thickness of $120 \mathrm{ft}, 103 \mathrm{ft}$, and $112 \mathrm{ft}$; net to gross ratio is $100 \%$ in Pennay 1, 2, 3 and 4, respectively. The average volume of shale is $8 \%$; as a result of this, the reservoir has a maximum porosity of $28 \%$ which is a clear indication that the reservoir has a large volume of sand deposit than shale, therefore, hydrocarbon saturated. The hydrocarbon saturation in the reservoir is $70 \%, 72 \%, 70 \%, 72 \%$ and $70 \%$ for Pennay $1-5$, respectively. The estimation of effective and relative permeability to oil hydrocarbon of Pennay 2, 1, 4, 3 and 5 are $0.559,0.61,0.56,0.61$ and 0.56 , respectively. Reservoir in sand $\mathrm{C}$ with thickness ranging from depths of 2778-3126 m for Pennay 1, 2783-3155 m for Pennay 2, 2870-3203 m for Pennay 3, and 2798-3159 m for Pennay 4 and $2779-3130 \mathrm{~m}$ for Pennay 5. Gross reservoir thickness is $122 \mathrm{~m}, 214 \mathrm{~m}, 333 \mathrm{~m}, 250 \mathrm{~m}$ and $214 \mathrm{~m}$ in Pennay 2, 1 , 4,3 and 5, respectively. It is characterized by an average gross thickness of $230 \mathrm{~m}$, with net to gross ratio of $84 \%$ in Pennay 1, 2, 3, 4 and 5, respectively. In Pennay 3 and 4, the resistivity log gives a little increase with combination of neutron and density logs crossover which might be an indication of gas and oil contact, while in Pennay 3 the resistivity log yields a minute increase which is an indication 


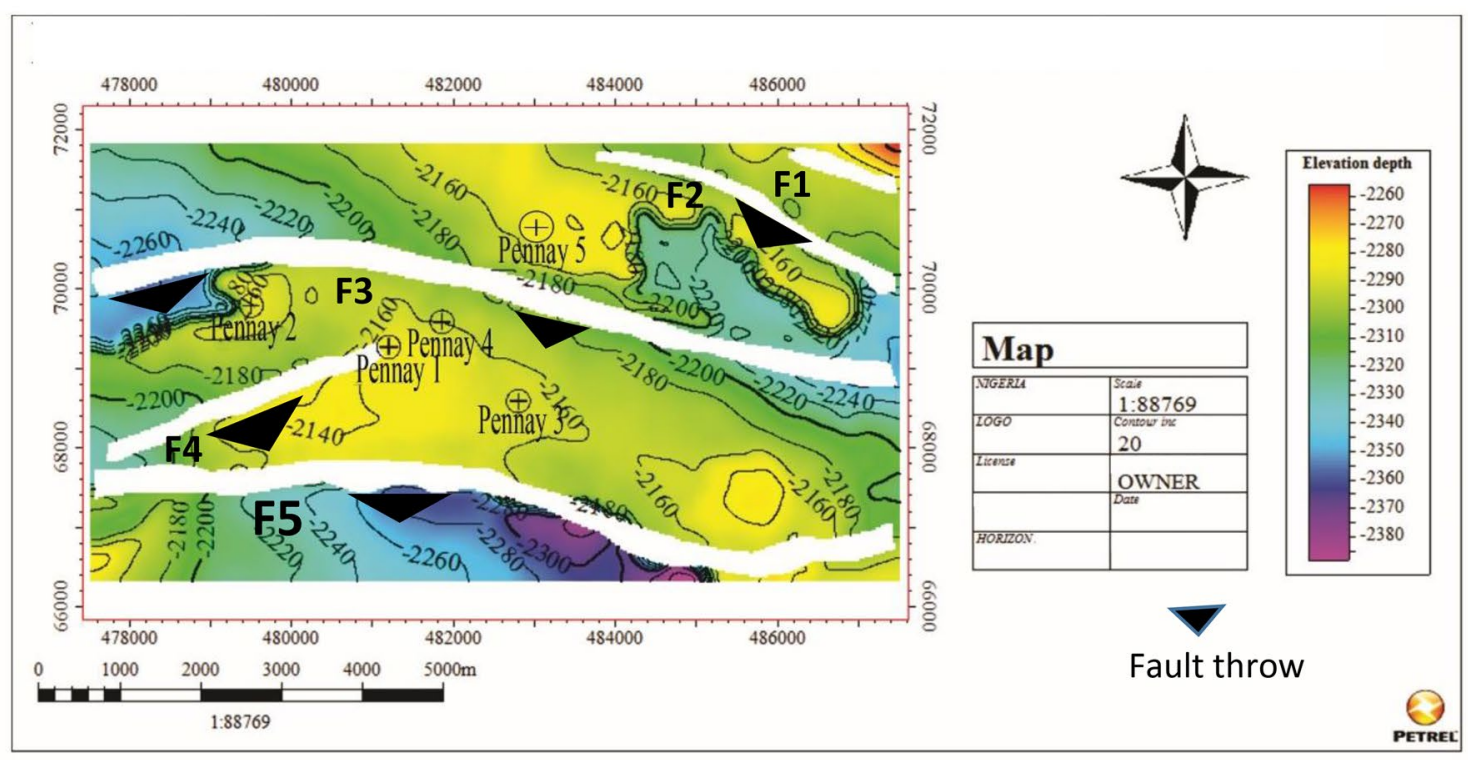

a Depth Structure Map of Horizon Sand A.

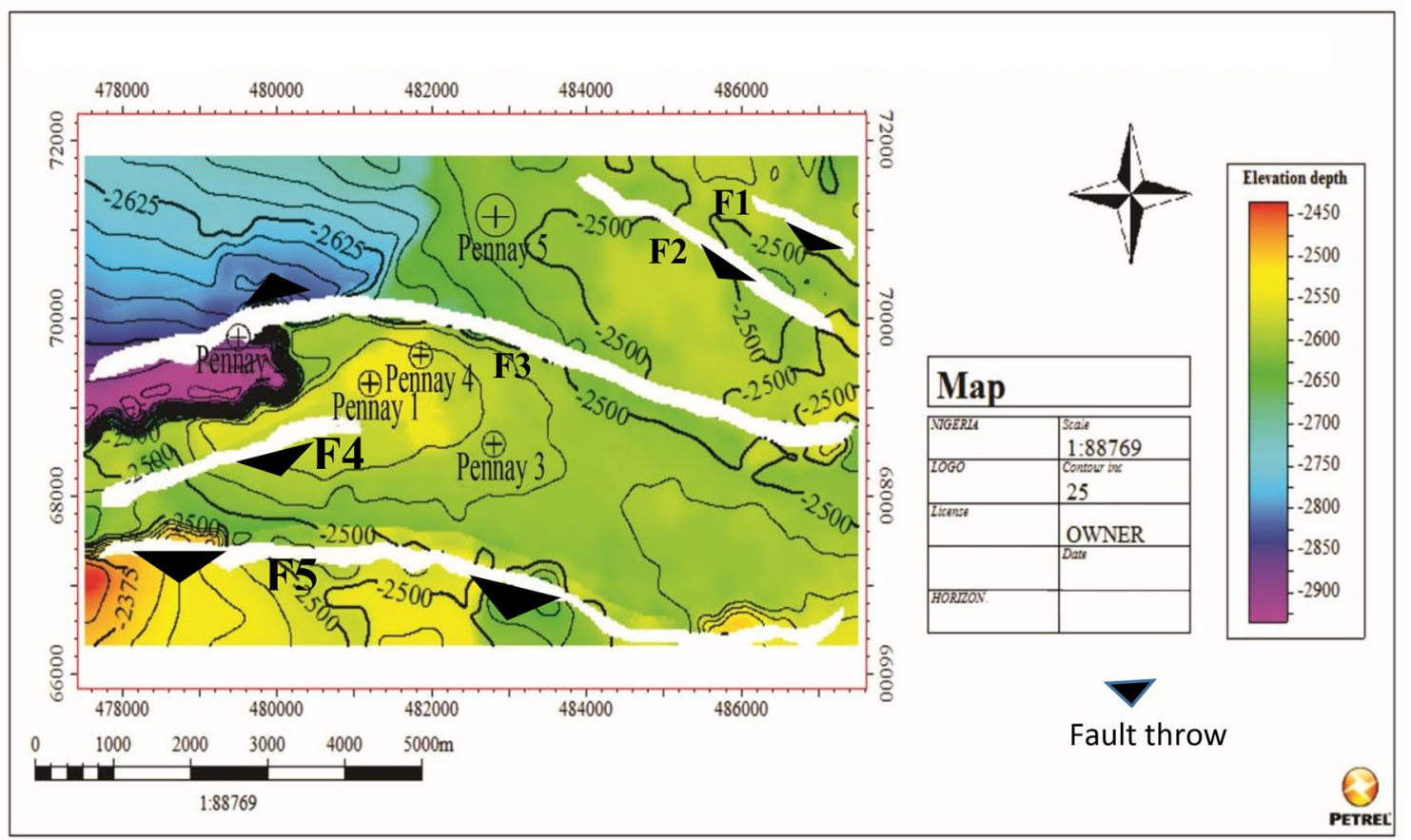

b Depth Structure Map of Horizon Sand B.

Fig. 8 a Depth structure map of horizon sand A. b Depth structure map of horizon sand B. c Depth structure map of horizon sand C. d Depth structure map of horizon sand D

of an oil and water contact. The average volume of shale in reservoir $\mathrm{C}$ is $15 \%$. Reservoir in sand $\mathrm{D}$ was penetrated by the wells at depth ranging from 3206 to $3501 \mathrm{~m}$ for Pennay 1, 3256-3389 m for Pennay 2, 3246-3496 m for Pennay 3, 3210-3320 m for Pennay 4 and 3209-3509 m for Pennay 5. Gross reservoir thickness is $66 \mathrm{~m}, 32 \mathrm{~m}, 27 \mathrm{~m}, 36 \mathrm{~m}$ in
Pennay 2, 1, 4 and 3, respectively. It was characterized by an average volume of shale of $18 \%$. The reservoir is thin in the SE and thickens toward the NW; this probably could be attributed to deformation or tectonic activities in the area of study. 


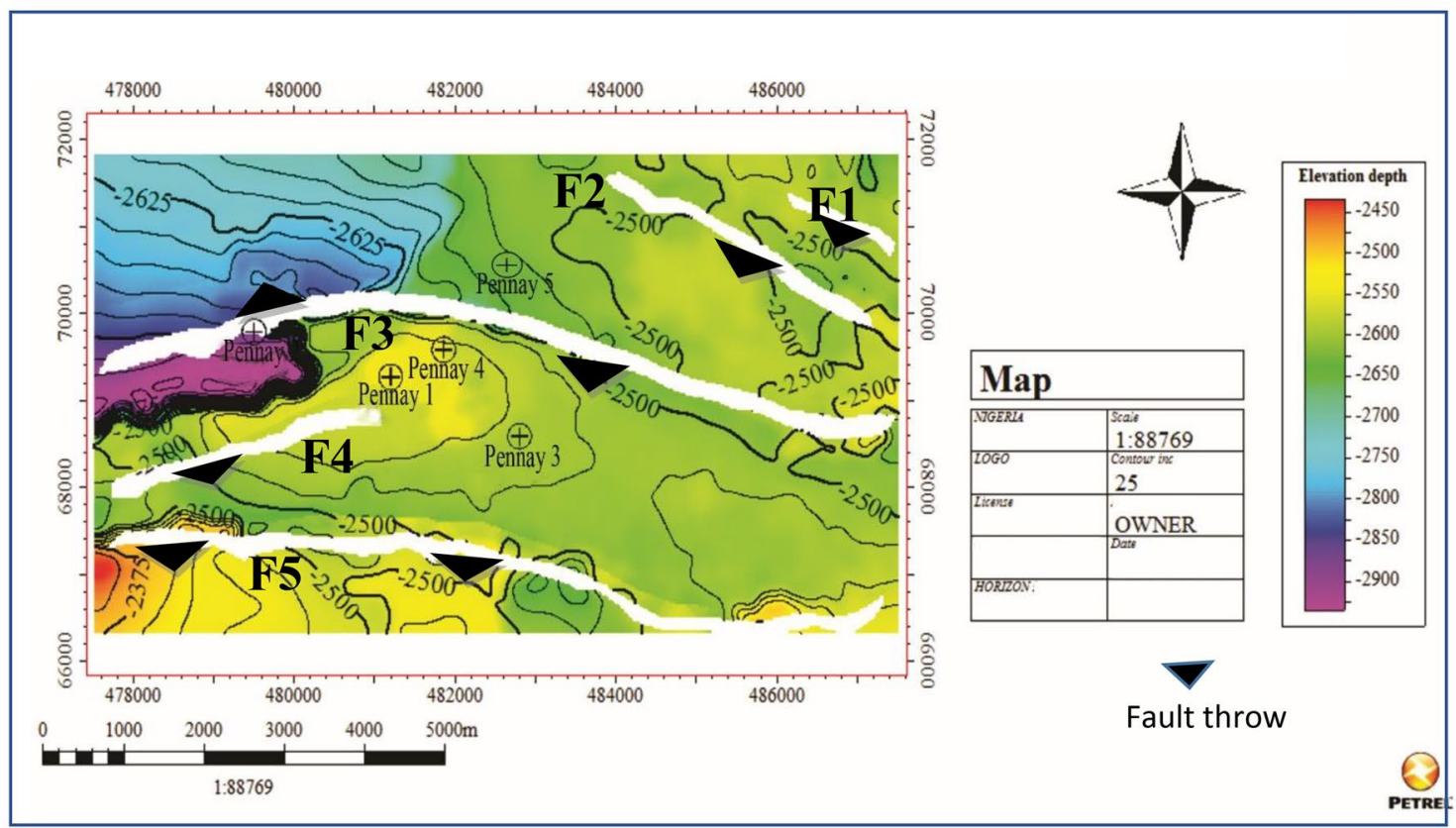

C Depth Structure Map of Horizon Sand C.

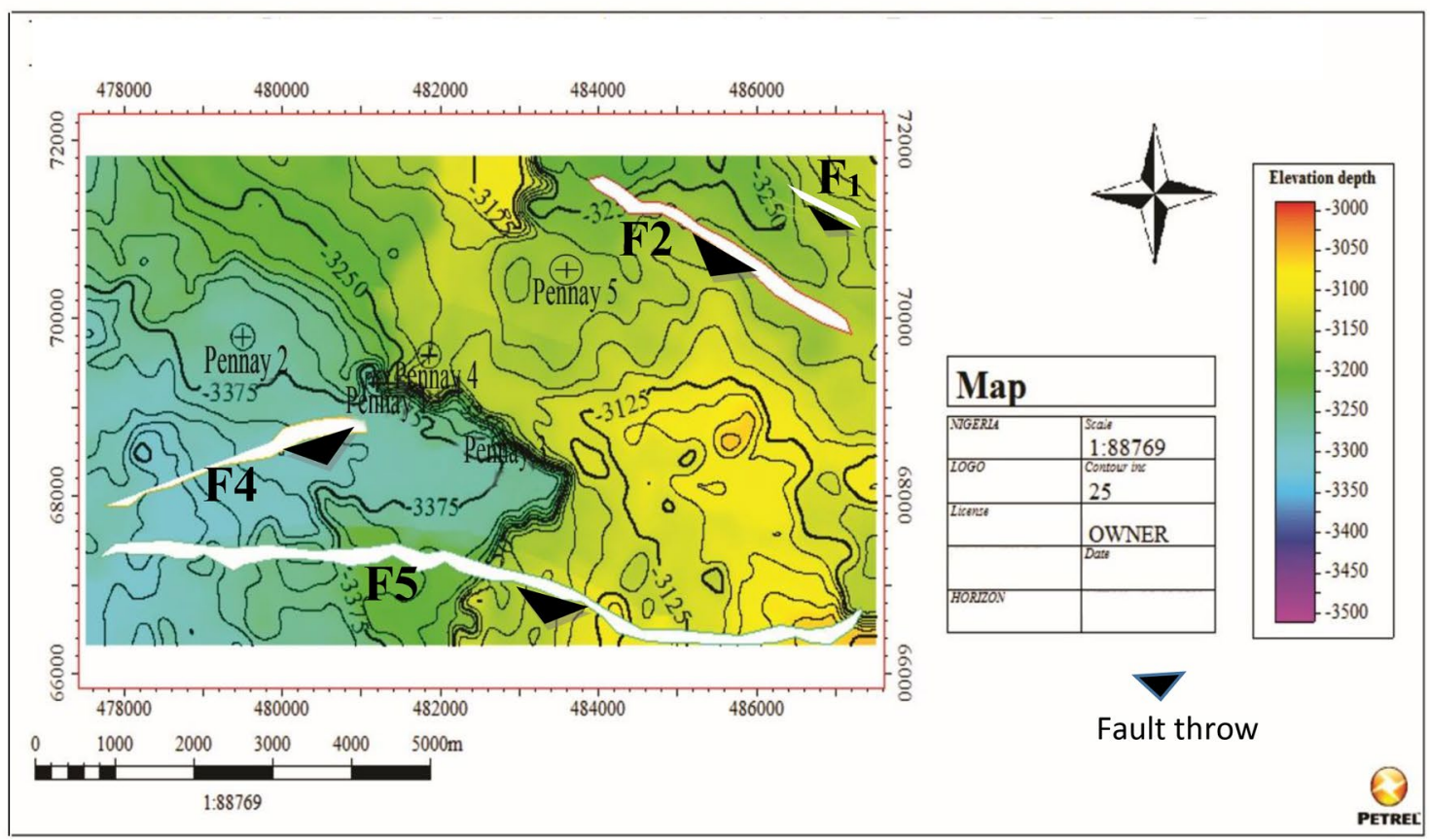

d Depth Structure Map of Horizon Sand D.

Fig. 8 (continued)

\section{Proven reserve estimation (1P/P90)}

The reserve resource accumulations in the Pennay field for the four-mapped reservoir sand-bodies have a total proven $(1 \mathrm{P})$ reserve estimate of $53.005 \mathrm{MMBO}$ at $1 \mathrm{P} / \mathrm{P} 90$
(Fig. 9a) (Table 2). C-unit, the only interval with a gas cap, has a 1P volume of 7737MMscf of free gas (Table 2). These oil and gas volumetric values yield a 1P/P90 total of 137.30MMBOE (Table 2). Reservoirs B and D have the highest recoverable oil (Fig. 9b) with 1P values of 
Table 2 Proven Reserve Resources Estimate at 1-P/P90 for ROI 1

\begin{tabular}{|c|c|c|c|c|c|c|c|c|c|c|c|c|c|c|}
\hline 1-P & (a) $\mathbf{P 9 0}$ & & & & & & & & & & OIL & & GAS & \\
\hline \multirow[t]{2}{*}{ Reservoir } & GRV & Area & NTG & $\Phi$ & $S_{w}$ & OOIP & $\begin{array}{l}\mathrm{Bo} / \\
\mathrm{Bg}\end{array}$ & STOIIP & GIIP & RF & Reserve & GOR & DG & FG \\
\hline & $\begin{array}{c}\text { Acre- } \\
\text { ft }\end{array}$ & Acres & Frac & Frac & Frac & МMB & & ММво & MMsef & & ММВО & scf/bbl & MMsef & MMscf \\
\hline A & 6980 & 357 & 0.705 & 0.310 & 0.560 & 5.207 & 1.800 & 2.893 & & 0.35 & 1.013 & 37500 & 37971.3 & \\
\hline B & 31198 & 676 & 0.490 & 0.240 & 0.400 & 27.079 & 1.800 & 15.044 & & 0.35 & 5.265 & 37500 & 124532.3 & \\
\hline $\mathrm{C}$ & 14955 & 418 & 0.840 & 0.270 & 0.380 & & 0.004 & & 10315.8 & 0.75 & & & & 7736.8 \\
\hline $\mathrm{C}$ & 13880 & 589 & 0.840 & 0.270 & 0.380 & 7.373 & 1.800 & 4.096 & & 0.35 & 1.434 & 37500 & 53757.9 & \\
\hline \multirow[t]{2}{*}{ D } & 78786 & 1027 & 0.545 & 0.237 & 0.303 & 55.030 & 1.800 & 30.572 & & 0.35 & 10.700 & 37500 & 401257.7 & \\
\hline & & & & & & 94.689 & & 53.005 & 10315.8 & & 18.412 & & 617519.3 & 7736.8 \\
\hline & & & & & & & & & & & & \multicolumn{2}{|c|}{ TOTAL MMBOE } & 137.30 \\
\hline
\end{tabular}

Table 3 Proven Reserve Resources Estimate at 2-P/P50 for ROI 1

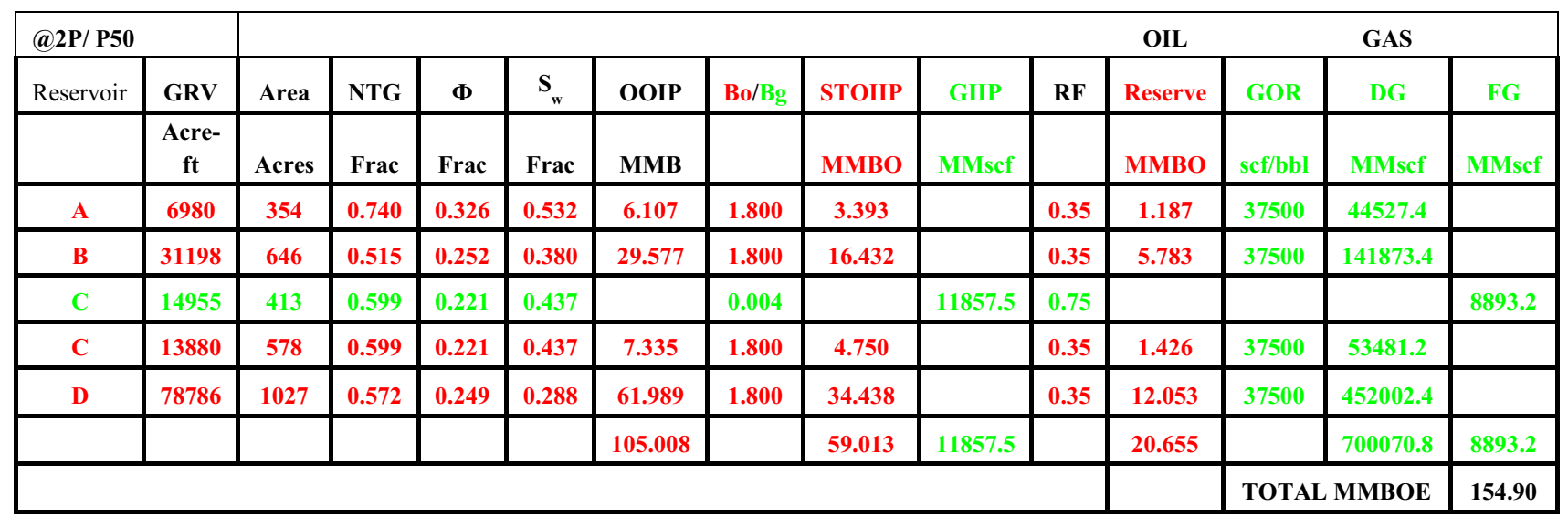

Table 4 Proven Reserve Resources Estimate at 3-P/P10 for ROI 1

\begin{tabular}{|c|c|c|c|c|c|c|c|c|c|c|c|c|c|c|}
\hline \multicolumn{11}{|c|}{ 3C/3P@ P10 } & \multicolumn{2}{|l|}{ OIL } & \multicolumn{2}{|l|}{ GAS } \\
\hline Reservoir & GRV & Area & NTG & $\Phi$ & $\mathbf{S}_{w}$ & OOIP & $\mathrm{Bo} / \mathrm{Bg}$ & STOIIP & GIIIP & RF & Reserve & GOR & DG & FG \\
\hline & Acre-ft & Acres & Frac & Frac & Frac & ММВ & & ММво & MMscf & & ММво & scf/bbl & MMscf & MMscf \\
\hline $\mathbf{A}$ & 6980 & 354 & 0.777 & 0.342 & 0.505 & 7.115 & 1.800 & 3.953 & & 0.35 & 1.384 & 37500 & 51881.7 & \\
\hline B & 31198 & 646 & 0.540 & 0.265 & 0.361 & 32.109 & 1.800 & 17.838 & & 0.35 & 6.244 & 37500 & 161208.8 & \\
\hline $\mathrm{C}$ & 14655 & 413 & 0.628 & 0.232 & 0.415 & & 0.004 & & 13580.3 & 0.75 & & & & 10185.2 \\
\hline $\mathrm{C}$ & 13880 & 578 & 0.628 & 0.232 & 0.415 & 9.669 & 1.800 & 5.3711 & & 0.35 & 1.880 & 37500 & 53481.2 & \\
\hline \multirow[t]{2}{*}{ D } & 78786 & 1027 & 0.601 & 0.261 & 0.273 & 69.724 & 1.800 & 38.736 & & 0.35 & 13.557 & 37500 & 508403.9 & \\
\hline & & & & & & 118.617 & & 65.898 & 13580.3 & & 23.064 & & 791996.1 & 10185.2 \\
\hline & & & & & & & & & & & & \multicolumn{2}{|c|}{ TOTAL MMBOE } & 171.51 \\
\hline
\end{tabular}

GAS

OIL 

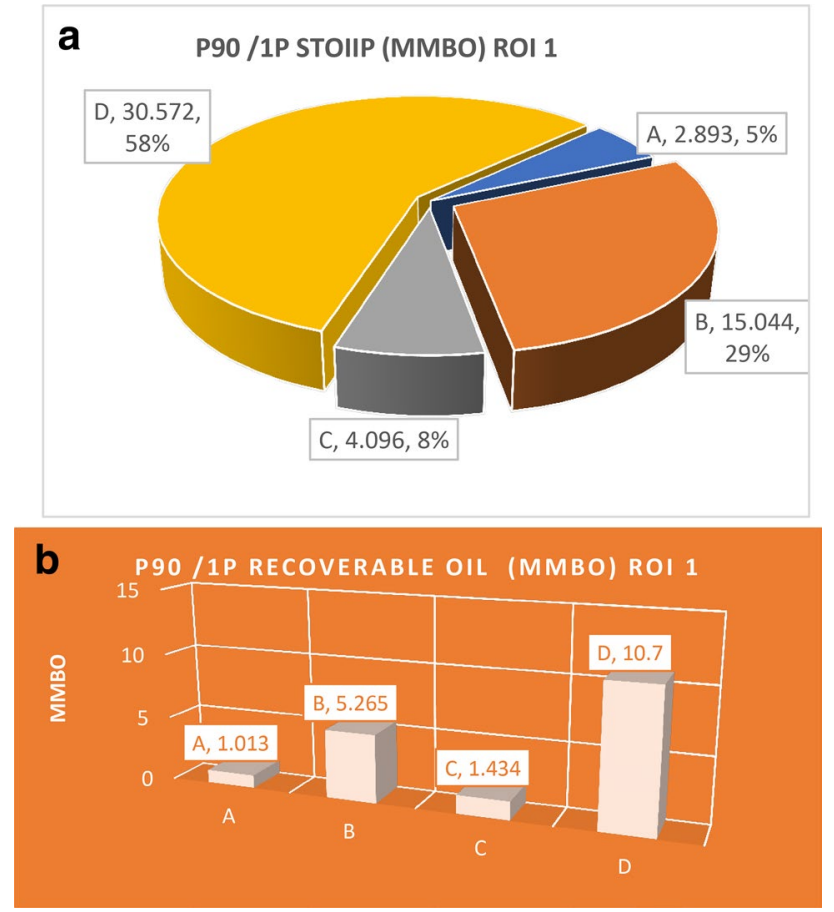

Fig. 9 a P90/1P STOIIP pie chart of reservoirs A-D at ROI 1. b P90/1P recoverable oil chart of reservoirs A-D at ROI 1

5.265MMBO and 10.70MMBO, respectively (Table 2). This proven reserve estimation is also referred to as low estimate.

\section{Probable reserve estimation (2P/P50)}

Probable reserve estimation (2P/P50) is also called the best estimate of petroleum reserve accumulations at Pennay field; the four-mapped reservoir sand bodies have a total probable reserve estimate of 59.013MMBO at 2P (Fig. 10a) (Table 3). $\mathrm{C}$-unit, the only interval with a gas cap, has a $2 \mathrm{P}$ volume of 8893.2MMscf of free gas (Table 3). These oil and gas volumetric values yield a 2C/2P at P50 total of 154.9MMBOE (Table 3). Reservoirs D and $\mathrm{B}$ have the highest recoverable oil (Fig. 10b) with 2P values of $12.053 \mathrm{MMBO}$ and 5.783MMBO, respectively (Table 3 ).

\section{Possible reserve resource estimation (3P/P10)}

The petroleum reserve accumulations in the Pennay field for the four-mapped reservoir sand bodies have a total possible (1P) reserve resource estimate of $65.898 \mathrm{MMBO}$ at $3 \mathrm{P}$ (Fig. 11a) (Table 4). C-unit, the only interval with a gas cap, has a 1P volume of 10185.2MMscf of free gas (Table 4). These oil and gas volumetric values yield a $3 \mathrm{C} / 3 \mathrm{P}$ at $\mathrm{P} 10$ total of 171.515MMBOE (Table 4). Reservoirs D and B have the highest recoverable oil (Fig. 11b) with $1 \mathrm{P}$ values of 13.557MMBO and 6.244MMBO, respectively (Table 4). a
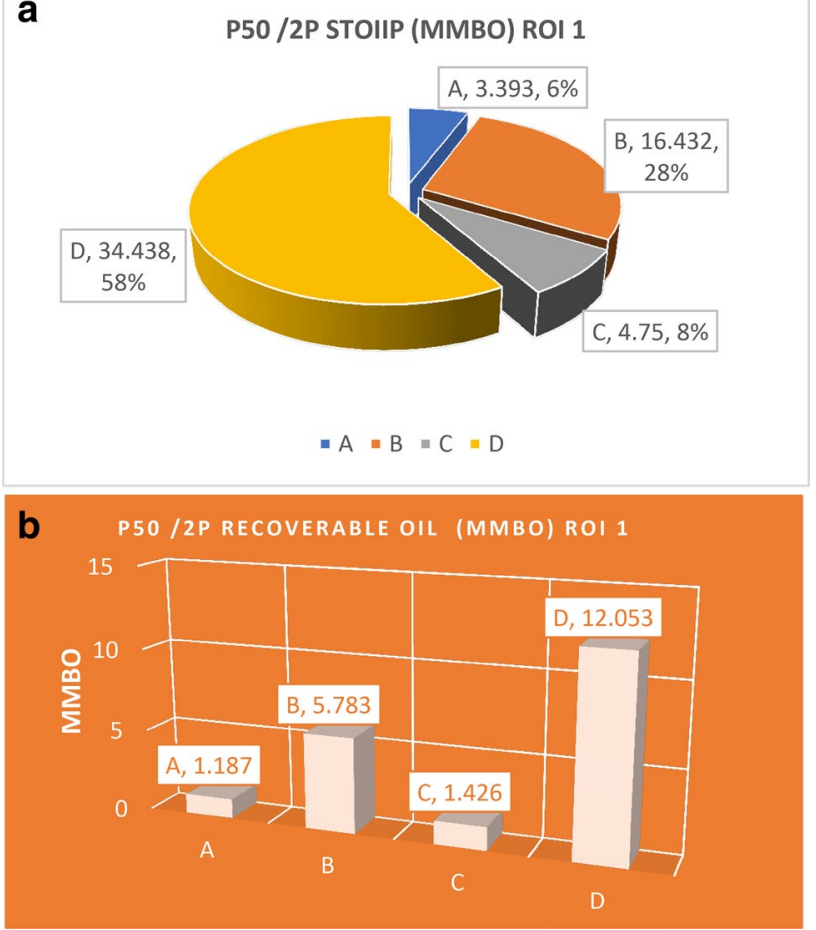

Fig. 10 a P50/2P STOIIP pie chart of reservoirs A-D at ROI 1. b $\mathrm{P} 50 / 2 \mathrm{P}$ recoverable oil chart of reservoirs A-D at ROI 1
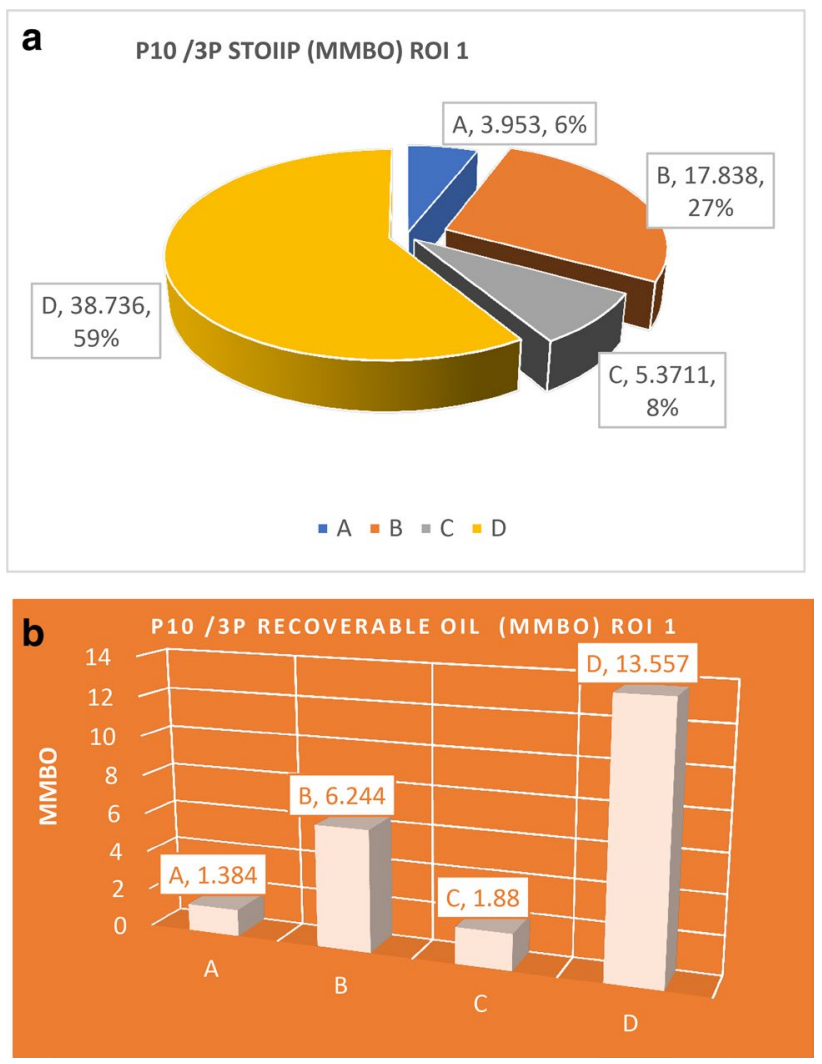

Fig. 11 a P10/3P STOIIP pie chart of reservoirs A-D at ROI 1. b P10/3P recoverable oil chart of reservoirs A-D at ROI 1 
This proven reserve estimation is also referred to as high estimate.

\section{Conclusions}

The study has shown the effectiveness of integrating well $\log$ and seismic data in estimation of reservoir petrophysical properties and evaluation of hydrocarbon latent of reservoirs, and also to influence development choices. Results of this study also revealed the efficiency of integrating petrophysical appraisal and seismic interpretation in evaluating hydrocarbon resource potential of reservoirs and also to reach development verdicts. The necessity to enhance production from the field of study has led to comprehensive description of the reservoirs in terms of structure and hydrocarbon volume. The detailed characterization of the reservoirs in relations to structure and petrophysical properties will bring about the needed production optimization in this field. Moreover, the results will help to plan the development method and guesstimate production, and also helpful in providing effective reservoir management approach. Four hydrocarbon-bearing sands, namely Pennay 1, 2, 3 and 4 were delineated from the study area. The area is characterized by the following petrophysical properties: gross ranges between 108 and $361 \mathrm{~m}$, net/gross: 78-96\%, Ø: 27-31\%, $V_{\mathrm{sh}}: 7-20 \%, S_{\mathrm{h}}: 56-72 \%, S_{\mathrm{w}}: 28-44 \%$, Hcpv: $13-21 \%$ and $K: 300-1097$ md. Reservoirs B and D rank higher than other mapped reservoirs in the study area. They are characterized with high hydrocarbon saturation $72 \%$, low water saturation $28 \%$ and excellent porosity $31 \%$. These reservoirs are good reservoir with high oil saturation at irreducible water saturation, because water saturation values are low from 7.07 to $20 \%$, which means that the sand body in all the reservoirs is high and there will be high rate of free flow of hydrocarbon in all the reservoirs as corroborated by their permeability values. Four horizons corresponding to near top of delineated hydrocarbon-bearing sands were mapped after well to seismic tie and subsequently used to produce time maps and then depth structural maps using appropriate checkshot data. Three major faults (F2, F3 and F5 which are normal, listric concave in nature) and two antithetic (F1and F4) were identified. Structural closures identified as rollover anticlines and it also describe as four-way dip closure was displayed on the time/depth structure map. These structural closure hydrocarbon traps in the study area are found at the upthrown side of the fault F4. This study shows that the results of estimated petroleum reserve accumulations in the Pennay field for the four-mapped reservoir sand bodies have a total proven (1P) reserve resource estimate of 53.005MMBO at $\mathrm{P} 90,59.013 \mathrm{MMBO}$ at 2P/P50 and 65.898MMBO at 3P/P10. Reservoir $\mathrm{C}$, the only interval with a gas cap, has a volume of 7737MMscf of free gas at 1P, 8893.2MMscf at 2P and
10185.2MMscf at 3P. These oil and gas volumetric values yield at 1P/P90 total of 137.30MMBOE, 154.9MMBOE at $2 \mathrm{P}$ and $171.515 \mathrm{MMBOE}$ at $3 \mathrm{P}$. Reservoirs $\mathrm{B}$ and $\mathrm{D}$ have the highest recoverable oil at $1 \mathrm{P}, 2 \mathrm{P}$, and $3 \mathrm{P}$ values of 5.265MMBO and 10.70MMBO, 12.053MMBO and 5.783MMBO, 13.557MMBO and 6.244MMBO, respectively. The result will help to plan the development approach and forecast production, and also helpful in providing very effective reservoir management strategy throughout the life of the field. Further fault seal analysis should be carried out on the two major faults accumulating these hydrocarbon quantities to check efficiency of these faults in trapping the hydrocarbon. It is recommended that further studies should include with biostratigraphy data of all the wells. This will provide more reliable data for further interpretation of the field. Integrated studies such as drill stem test, repeat formation test results and engineering data should be added to the results of this study to further ascertain the fluid types identified in the wells and also give evidence that reservoir fluid is actually recoverable. These will contribute significantly to the efficient development of the hydrocarbon in Pennay field.

Open Access This article is distributed under the terms of the Creative Commons Attribution 4.0 International License (http://creativeco mmons.org/licenses/by/4.0/), which permits unrestricted use, distribution, and reproduction in any medium, provided you give appropriate credit to the original author(s) and the source, provide a link to the Creative Commons license, and indicate if changes were made.

\section{References}

Adeoye TO, Enikanselu PA (2009) Hydrocarbon reservoir mapping and volumetric analysis using seismic and borehole data over "Extreme"' field, southwestern Niger Delta. Ozean J Appl Sci 2(4):429-441

Aizebeokhai AP, Olayinka I (2011) Structural and stratigraphic mapping of EMI field, offshore Niger Delta. J Geol Min Res $3(2): 25-38$

Amigun JO, Adewoye O, Olowolafe T, Okwoli E (2014) Well logs-3D seismic sequence stratigraphy evaluation of "holu" field, Niger Delta, Nigeria. Int J Sci Technol 4:26-36

Archie GE (1942) The electrical reservoir log as an aid in determining some reservoir characteristics. Trans AME 146(19):pg 54-64

Asquith G, Krygowski D (2004) Basic Well Log Analysis Methods in Exploration. 2 Edition. American Association of Petroleum Geologists, Tulsa 16:123

Bateman RM, Konen CE (1977) The Log analyst and the programmable pocket calculator. Log Anal 18(5):3-11

Billoti F, Shaw JH (2005) Deep-water Niger Delta fold and thrust belt modeled as a critical-taper wedge: the influence of elevated basal fluid pressure on structural styles. Am Assoc Pet Geol Bull 89:1475-1491

BP (2014) Statistical review of world energy. http://www.bp.com/

Corredor F, Shaw JH, Bilotti F (2005) Structural styles in the deepwater fold and thrust belts of the Niger Delta. Am Assoc Pet Geol Bull 89:753-780

Doust H, Omatsola E (1990) Niger Delta. In: Divergent/passive margin basins. American association of petroleum geologists memoir

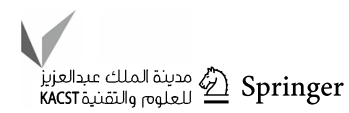


(Eds. Edwards JD and Santogrossi PA). 48, The American Association of Petroleum Geologists, Tulsa, USA, 239

Dresser, Atlas (1979) Log interpretation Charts. Houston Dresser Industries Inc. 1-10

Futalan K, Mitchell A, Amos K, Backe G (2012) Seismic facies analysis and structural interpretation of the Sandakan sub-basin, Sulu Sea, Philippines. AAPG international conference and exhibition (Singapore), http://www.searchanddiscovery.com/pdfz/docum ents/2012/30254futalan/ndx_futalan.pdf.html. Accessed 1 Sept 2017

Ihianle OE, Alile OM, Azi SO, Airen JO, Osuoji OU (2013) Three dimensional seismic/well logs and structural interpretation over ' $X-Y$ ' field in the Niger Delta area of Nigeria. Sci Technol $3(2): 47-54$

Onayemi J, Oladele S (2014) Analysis of facies and depositional systems of "Ray" field, on shore Niger Delta basin, Nigeria. SEG Annual Meeting, http://www.onepetro.org/conference-paper/ SEG2014-0019. Accessed 15 July 2017

OPEC (2017) Annual statistical bulletin. http://www.opec.org/opec web/ en/publications/202.htm. Accessed 20 Sept 2017

Oyedele K, Ogagarue D, Mohammed D (2013) Integration of 3D seismic and well log data in the optimal reservoir characterization of "Emi" field, off shore Niger delta oil province, Nigeria. Am J Sci Ind Res 4:11-21

Saeland GT, Simpson GS (1982) Interpretation of 3-D data in delineating a sub-unconformity trap in Block 34/10, Norwegian North Sea. In: MT Hallouty (ed) The deliberate search for subtle trap: American association of petroleum geologists memoir, 32. The American Association of Petroleum Geologists, Tulsa, pp 217-236

Shannon PM, Naylor N (1989) Petroleum basin studies: London, Graham and Trotman Limited, $\mathrm{p} 153$

Sheriff RE, Geldart LP (1983) Exploration seismology; v.2, data-processing and interpretation. Cambridge University Press, London, p 130

Short K, Stauble A (1967) Outline of geology of Niger delta. Am Assoc Pet Geol Bull 51:761-779

Stacher P (1994) Niger delta hydrocarbon habitat. Niger Assoc Pet Explor Bull 25(2):518-535

Stieber SJ (1984) The distribution of shale in sandstone and its effects on porosity. SPW sixteen annual logging symposium 47(5) pg 7

Timur A (1968) An investigation of permeability, porosity and residual water saturation relationship for sandstone reservoirs. Log Anal 9(4):12-25

Tixier MP (1956) Fundamentals of electrical logging-microlog and microlaterolog. In: Fundamentals of logging. Univ. Kansas, Petroleum Eng. Conf. 2 and 3, April 1956

Tuttle MLW, Charpentier RR, Brownfield ME (1999) The Niger Delta petroleum system: Niger Delta Province, Nigeria, Cameroon, and Equatorial Guinea, Africa, USGS open-file report, 99-50-H

Publisher's Note Springer Nature remains neutral with regard to jurisdictional claims in published maps and institutional affiliations. 